\title{
The Practice of Informal Changes to the Ethiopian Constitution in the Course of Application
}

\begin{abstract}
Nigussie Afesha *
"Where the natural path of formal amendment is difficult or blocked, alternative paths open to political actors to achieve its functional equivalent."
\end{abstract}

Richard Albert ${ }^{1}$

\begin{abstract}
Given the generality of a constitution, it requires amendments in order to enable it to cope up with the socio-economic and political dynamics. As a result, formal constitutional amendment procedures have remained vital mechanisms in this regard. However, the rigidity of formal constitutional amendment procedures and/or the political context of a country have often kept constitutions static and frequently induce politicians to look for alternatives. Informal constitutional amendment mechanisms are thus designed in response to the difficulty of formally amending the constitution. In this sense, the role of non-constitutional mechanisms in the alteration of a constitution is essential. The FDRE Constitution encompasses a constitutional provision that spells out how the Constitution can be amended. However, there has not yet been a single formal constitutional amendment. This article examines instances of actual but unwritten constitutional changes in the course of application that have been occurring in Ethiopia for which formal constitutional amendment cannot account for. These include constitutional changes through constitutional interpretation, or by legislation. The article contends that there are time-honoured practices that regulate and continue to guide the course of the Ethiopian federal state in contradiction to the Constitution. Equally important, party structure also influences the federal distribution of power.
\end{abstract}

\section{Key terms}

FDRE Constitution, informal constitutional changes, constitutional amendment, constitutional interpretation, political custom, law enforcement, Ethiopia.

DOI http://dx.doi.org/10.4314/mlr.v10i2.4

\footnotetext{
* Nigussie Afesha, (Asst. Professor) at Hawassa University, College of Law and Governance, School of Law.

I thank Bisrat Mulugeta for his comments and helpful discussion. I am also grateful to Elias N. Stebek (for his invaluable comments and insightful suggestions) and the anonymous reviewers for their contributions toward the improvement of the article.

${ }^{1}$ Richard Albert (2014), "Constitutional Disuse or Desuetude: The Case of Article V, Boston College Law School”, Legal Studies Research Paper Series, No, 327 p. 1062.
} 


\section{Introduction}

A constitution outlines the major principles and the basic organization, structure, and process of a state. ${ }^{2}$ Most of its content is brief, and "constitutions, by their nature, operate in time, seeking to regulate the future on behalf of the past." Many drafters of constitutions act as if their handiwork should last for a long period of time. ${ }^{4}$ Indeed, every normative constitutional theory presumes that constitutions are able to function over a relatively extended period of time. Without endurance, constitutions cannot provide a stable basis of politics. This assumption of endurance is built into the very idea of a constitution and closely related to core normative issues, such as constitutional amendment. ${ }^{5}$

The idea of constitutional amendment stems from the argument that no generation has a monopoly on knowledge enabling it to bind future generations irreversibly, and that "a constitution that will not bend will break". There is thus an 'inherent right' to amend a constitution in order to perfect 'imperfections' and to strengthen its provisions where necessary. ${ }^{7}$ Amendment denotes the idea of making correction or improvement in the text of a written constitution. ${ }^{8}$ Formal constitutional amendment is more of a norm and continues as a widely shared and intrinsic quality of national constitutions. ${ }^{9}$ The primary means of legitimate adjustment on constitutional document is a formal procedure specified in the Constitution itself. ${ }^{10}$ It is equally important to bear in

\footnotetext{
${ }^{2}$ Donald J. Boudreaux and A. C. Pritchard (1993), Rewriting the Constitution: An Economic Analysis of the Constitutional Amendment Process, Fordham L. Rev. Vol., 62, Pp. 111162, p. 111.

${ }^{3}$ Tom Ginsburg (2011), "Constitutional endurance" in Tom Ginsburg and Rosalind Dixon, eds., Comparative Constitutional Law, Edward Elgar Publishing, p. 112.

${ }^{4}$ Ibid.

${ }^{5}$ Ibid.

${ }^{6}$ John Hatchard, Muna Ndulo, Peter Slinn (2004), Comparative Constitutionalism and Good governance in the Commonwealth: An Eastern and Southern African Perspective, Cambridge University Press, New York, pp. 44-45.

${ }^{7}$ Ibid.

${ }^{8}$ Rosalind Dixon (2011), "Constitutional Amendment Rules: A Comparative Perspective" in Tom Ginsburg and Rosalind Dixon, eds., Comparative Constitutional Law, Edward Elgar Publishing, p 96.

${ }^{9}$ Ibid.

${ }^{10}$ Bjørn Erik Rasch, (2008), Foundations of Constitutional Stability: Veto Points, Qualified Majorities, and Agenda-Setting Rules in Amendment Procedures, A Paper presented at the ECPR Joint Sessions of Workshops Rennes, France, April 11-16, 2008 pp. 34[Hereinafter called, Bjørn Erik Rasch, Foundations of Constitutional Stability].
} 
mind that the more fundamental the constitutional change, the weightier becomes the reason for resorting to formal processes. ${ }^{11}$

However, there are arguments over the function of formal procedures for constitutional amendment and comparative difficulty of such processes. ${ }^{12}$ Most constitutional scholars agree that not all forms of constitutional change in fact involve formal constitutional amendment processes. Some even have suggested, ultimately formal constitutional amendments will be irrelevant to shape constitutional meaning. ${ }^{13}$ Irrespective of these arguments, constitutions have special procedures and require the involvement of majorities for their amendment, often requiring some measure of consent from the legislatures or the public. ${ }^{14}$ Nevertheless, amendment rules have often made constitutions difficult to change and the politics of their constitutional amendment has proven to be very divisive. As a consequence, several countries frequently look for alternatives to formal constitutional amendment mechanisms. ${ }^{15}$ In this regard, the role of non-constitutional mechanisms in the alteration of the Constitution is essential. In particular, the function, relation and co-existence of formal and non-formal constitutional amendment mechanisms need to be clearly spelled out. The extent to which and the circumstances under which informal constitutional mechanisms modify the contents of a given constitution need to be ascertained.

The FDRE Constitution expressly provides for the mechanisms of its modification which includes, setting different amendment formula to amend various sections of the Constitution. ${ }^{16}$ The Constitution also expresses that a proposed constitutional amendment is required to be submitted for discussion and decision to the general public and to those whom the amendment of the Constitution concerns. ${ }^{17}$ Despite this fact, the Constitution has not undertaken any formal amendment so far. The exception to this was the move to amend article $98^{18}$ of the Constitution, titled 'concurrent power of taxation' that gave the federal government the legislative and executive power over the concurrent taxation restricting the power of the state only to get the proceeds thereof.

\footnotetext{
${ }^{11}$ Getachew Assefa (2012), Ethiopian Constitutional Law with Comparative Notes and Materials: A Text book, p. 103.

${ }^{12}$ Ibid.

${ }^{13}$ Id., p. 100.

${ }^{14}$ George Anderson (2008), Federalism: An Introduction, Oxford University Press, p 59.

${ }^{15}$ Ibid.

${ }^{16}$ See article 105 of the FDRE Constitution.

${ }^{17}$ Id., article 104.

${ }^{18}$ Solomon Negussie (2008), Fiscal Federalism in the Ethiopian Ethnic-based Federal System, Rev. ed. Netherlands Wolf legal publishers p.64.
} 
In doing so, formal amendment was initiated, and the proposed amendment passed through a number of stages. However, Negarit Gazette did not proclaim the proposed amendment. ${ }^{19}$ In practice, this provision of the Constitution changed and, the federal government has been empowered to determine the scope of the tax as well as the rate, and administer the same (concurrent power of taxation), while the regional states are entitled for their share. Except for this circumstance, the Constitution has served for more than two decades without making a formal amendment. However, there are ample instances of actual but unwritten constitutional changes conceivably occurring in Ethiopia for which formal constitutional amendment cannot account for. One can thus argue that informal procedures for constitutional amendment can play a role in reconstituting the Constitution and to reset the constitutional meaning for subsequent constitutional developments.

This article examines these practices of informal constitutional changes in Ethiopia. The first section deals with conceptual and theoretical frameworks of constitutional amendment. The second section discusses formal constitutional amendments in general. This part explains textual amendments, which are usually considered as conventional vehicles for amending a Constitution. Section 3 takes up various mechanisms of non-textual ways of introducing changes in the life of the Constitution such as judicial interpretation, legislation, party practice and political customs. The Ethiopian experience of formal constitutional amendment and mechanisms of informal change are discussed in Sections 4 and 5. These sections further highlight historical and conceptual perspectives of formal and informal constitutional changes in Ethiopia.

\section{The Concept of Constitutional Amendment: A theoretical framework}

The constitution of any country is intended to capture the essence and wishes of the people. Such norms and desires of the people are dynamic and evolve after they are initially formed. ${ }^{20}$ In view of the dynamic nature of society and their aspirations over time, constitutions cannot remain immutable. ${ }^{21}$ Ginsburg argues that constitutions "exist in a world of change, and so must adjust to changing conditions". ${ }^{22}$ Amendment is a mechanism that preserves the continuity of the

\footnotetext{
${ }^{19}$ Ibid.

${ }^{20}$ Rosalind Dixon (2010), “Amending Constituting Identity”, Chicago Public Law and Legal Theory, Working paper No. 332, p. 1.

${ }^{21}$ Gabriel L. Negretto (2011), Replacing and Amending Constitutions: The Logic of Constitutional Change in Latin America, paper prepared for delivery at the 2011 American Political Science Association Meeting, Seattle, Washington, September 1-4, p 751.

${ }^{22}$ Ginsburg (2011) supra note 3, p. 112.
} 
constitution in a changing environment. ${ }^{23}$ By implication, constitutional amendment processes are of foundational value for making changes, and allow political actors to respond to the changing political, social, and economic needs of the political community. ${ }^{24}$ For this reason, every constitution must provide some method by which it could be amended as conditions and circumstances dictate to make periodic reconsideration of fundamental principles. A constitution is supposed to be changed in ways that the provision of the constitution describes. ${ }^{25}$ It is imperative that the essence of amendment be sufficiently articulated and understood.

Rosalind Dixon defines constitutional amendment as the idea of making correction or improvement upon prior constitutional design choices in light of new information, evolving experiences or political understandings. ${ }^{26} \mathrm{He}$ contends that constitutional 'amendment' generally requires some kind of formal legal deposit in the text of a written constitution. ${ }^{27}$ Unlike ordinary legislation, constitutions thus commonly entrench one or more amendment formula to modify their text. ${ }^{28}$ Providing a legal and transparent framework that enables to alter the constitution ${ }^{29}$ and fix defects (revealed by time and experience) is an essential function of formal amendment rules. ${ }^{30}$ Formal amendment rules structure the process by which political actors change the text and meaning of a constitution. ${ }^{31}$ This may lead to the argument that a formal constitutional amendment process can be (and are typically) used to a wide range of constitutional alterations. However, this is not tantamount to requiring every constitutional modification to pass through the formal amendment channels.

In support of informal amendment, Strauss argues that formal amendments, which are adopted in a constitution, are actually not a very important way of changing it. ${ }^{32}$ "Most constitutional scholars agree that not all forms of constitutional change in fact involve formal processes of constitutional amendment". ${ }^{33}$ The claim here is that some forms of modification can be made

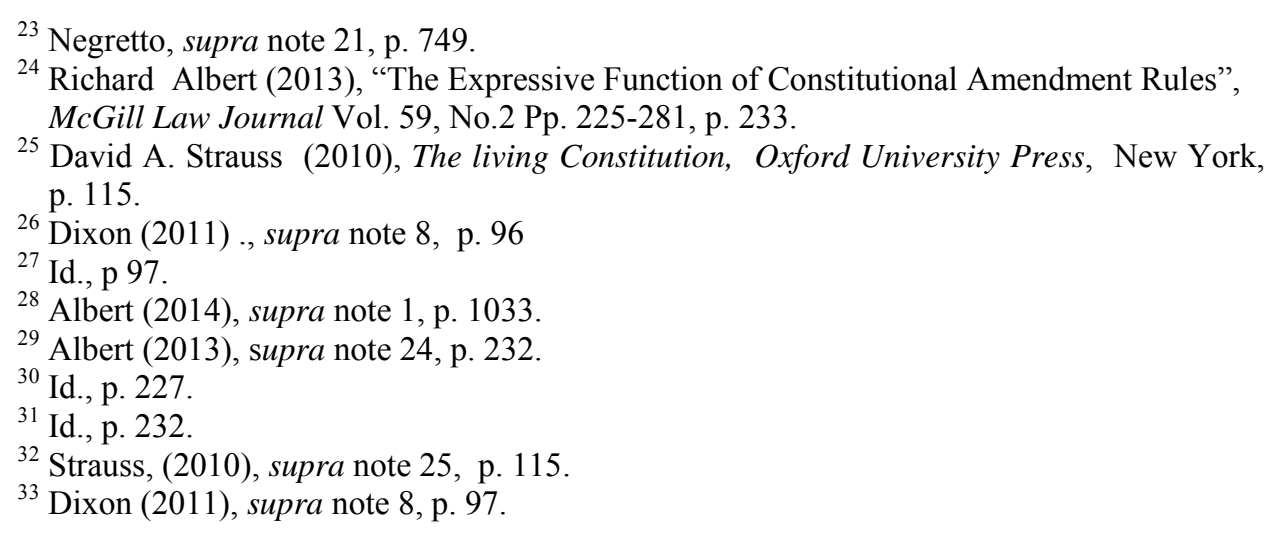


informally without setting the constitutional amendment process in motion. This is because some institutions like courts and legislative bodies are also established to undertake such task. As Richard Albert noted, although the idea of formal amendment has American roots, as expressly embodied in Article V of the United States Constitution, ${ }^{34}$ the pace of formal amendment in the United States is decelerating. ${ }^{35}$ And now, the dominant mode of 'updating' constitutional meaning has turned out to be via a process of judicial interpretation. ${ }^{36}$ This leads to an argument that constitutions can be modified over time without textual changes, typically by means of constitutional court rulings and, less visibly, by legislative and executive decisions, or by the informal practices of political actors'. ${ }^{37}$

One may generally state informal amendment as a process involving alteration of constitutional meaning in the absence of textual change. ${ }^{38}$ An informal amendment occurs when political norms change, or courts, the most conventional actors of informal amendment, interpret or construct the constitution so as to bring it in line with policy preferences. ${ }^{39}$ Hence, political actors alter constitutional meaning or update the constitutional text informally without a corresponding alteration to the constitutional text as time and experience expose faults in its design and new challenges emerge in the constitutional community.

It can be argued that formal amendment rules provide a legal and transparent framework within which a constitution can be altered, whereas informal amendment occurs supposedly pursuant to extralegal procedures. To call informal amendment 'extralegal' is not to make a claim against its legitimacy. ${ }^{40}$ For that matter, the purpose of describing formal amendment rules as 'legal' and informal amendment procedures as 'extralegal' is merely meant to highlight that the former is vividly outlined in a constitutional text while the latter is entrenched within it. ${ }^{41}$ Put differently, the difference between formal and informal amendment is not that one is a set of legal rules and the other is not; it is, that the former is textually entrenched through legal rules while the latter is not. ${ }^{42}$ It should be noted here that both formal and informal amendments adjust

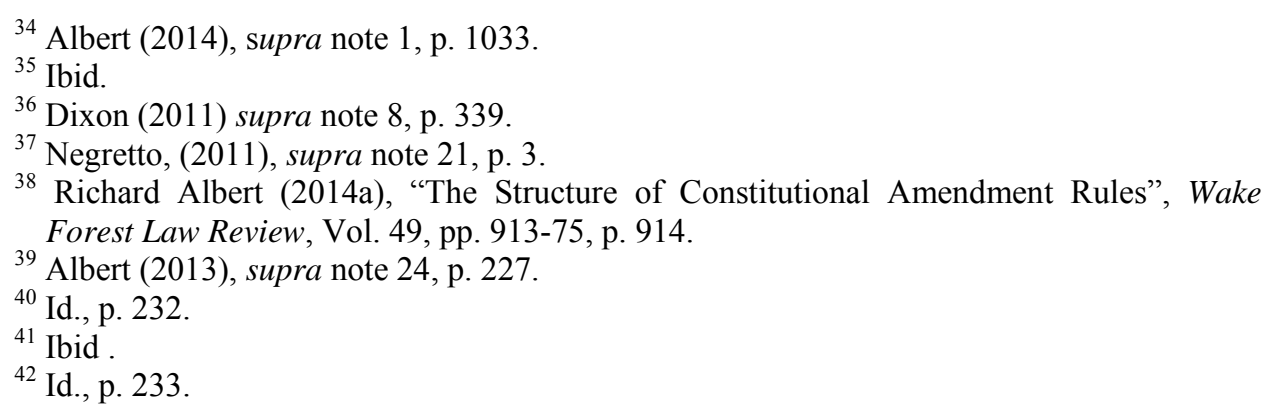


basic constitutional values in tune with changing political and social circumstances by incorporating into a constitution a broader and more inclusive understanding of these values. ${ }^{43}$

\section{Formal Constitutional Amendment}

Constitutions obsolesce rapidly, and must be updated over time to cope with changes in the country's circumstances and citizens' values. ${ }^{44}$ Changing social circumstances and understandings will often make provisions of a constitution outdated. ${ }^{45}$ Therefore, a constitution is expected to regulate new/dynamic circumstances that have evolved after the constitution was initially framed. The issue here is: what process should be followed in updating a constitution? Richard, in this regard, notes that fixing defects of a constitution is an essential function of formal amendment rules. ${ }^{46}$ Getachew also underlines that amendment "is without any doubt the most formal way in which a constitution takes care of problems it suffers". ${ }^{47}$ It is thus natural for a constitution to describe the principal modes of changing its rules, be it the substance of the provision or its scope of applicability. If periodic replacement of a constitution is not feasible, the next plausible option is sticking to a formal constitutional amendment process, which is stated in the constitution itself. In this sense, formal constitutional amendment procedures have important functions in a constitutional democracy. In cases of major constitutional change, they help to ensure that change occurs via legal, rather than extra-legal, means. ${ }^{48}$

As Albert states: "[i]n the normal course of affairs, a state amends its constitution in accordance with the constitutional amendment procedures spelled out in the constitutional text. These amendment procedures will typically identify the individuals, institutions or bodies" that are authorized to propose an amendment to the existing constitution and they prescribe the necessary and sufficient conditions for amending the same. ${ }^{49}$ Thus, amendment becomes valid only if it adheres to the procedural requirements set out in detail in the Constitution and is proposed by those persons who are authorized to do so. Such amendment becomes law only if it meets those, often stringent, requirements.

\footnotetext{
${ }^{43}$ Albert (2014), supra note 1, p. 1061.

${ }^{44}$ Adrian Vermeule (2004), "Constitutional Amendments and the Constitutional Common Law", Chicago Public Law and Legal Theory Working Paper, no. 73 p. 1.

${ }^{45}$ Rosalind Dixon and Richard T. Holden (2011), "Constitutional Amendment Rules: The Denominator Problem", Chicago, Public Law and Legal Theory Working Paper, No. 346, p. 1.

${ }^{46}$ Albert, (2013), supra note 24, p. 227.

${ }^{47}$ Getachew, supra note 11, p. 103.

${ }^{48}$ Dixon and Holden (2011), supra note 45, p. 1.

${ }^{49}$ Richard Albert, (2010), "Nonconstitutional Amendments", Canadian Journal of Law and Jurisprudence, Vol. xxii, No.1 pp. 1- 43, p. 13.
} 
The textual procedures are, therefore, "both the beginning and the end of the constitutional amendment process". ${ }^{50}$ It is only when the amendment effort successfully goes through the procedures that it would introduce changes into the written constitutional order. ${ }^{51}$

However, there are substantive limits to valid constitutional changes. These occur where a constitution contains "Eternal Clause" or "unamendable" provisions. ${ }^{52}$ This relates to constitutional provisions that immunize certain provisions of a constitution against amendment. These parts of the constitution can be altered neither by judicial construction nor through constitutionally entrenched amendment procedures. ${ }^{53}$ Changing an unamendable constitutional provision is unthinkable except through comprehensive constitutional renewals that would bring about a paradigm shift. ${ }^{54}$

Save the issue of eternal clause as an exception to a formal amendment process, countries have different amendment requirements which may be grouped into three general categories: legislative majority, double passage requirements (this is the case where the bill is expected to pass through two houses of parliament), and referendum requirements. ${ }^{55}$ Others (that opt to express the exact degree of difficulty) categorize amendment requirements into four groups: legislative supermajority requirements, parliamentary quorum requirements, state ratification, and referendum requirements. ${ }^{56}$

While affirming formal constitutional amendment mechanism is extremely important (and a necessary means) to introduce change into the constitution, the onerous nature of amendment requirements and the difficulty of adhering to the requirements spelled out in the constitution render a constitutional amendment difficult. For example, if an amendment is required to pass two Houses of parliament, its approval can be too difficult as compared to a bill which can be enacted by one house. ${ }^{57}$ The rigour of the process can be even more difficult if a bill is required to pass through a constituent unit legislative council as well. ${ }^{58} \mathrm{In}$ effect, stiff amendment requirements that were initially envisaged by framers of a constitution would inevitably cause the dilemma for countries between pursuance of the formal amendment path or looking for other mechanisms.

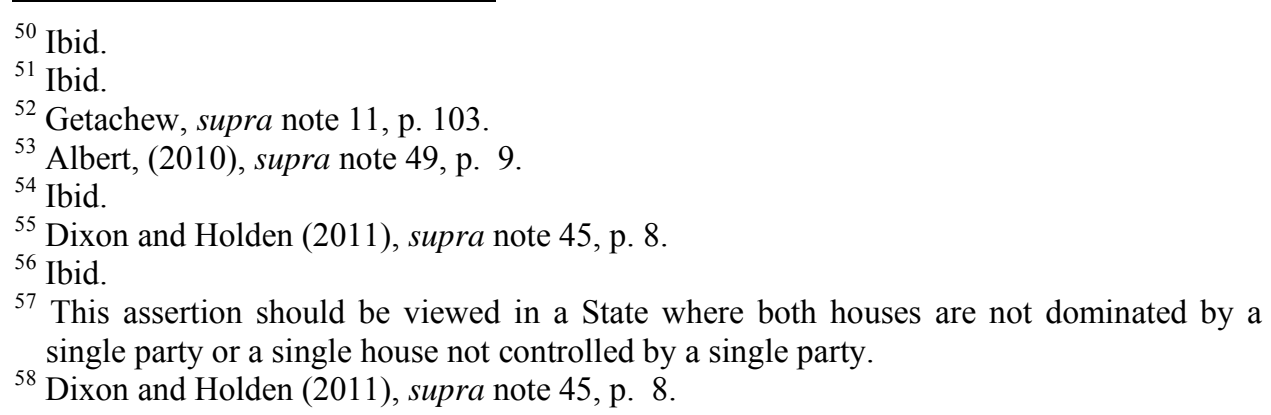


Based on this reasoning, we can find several examples of constitutional change that did not follow formal procedures laid down in constitutions. For example, the U.S. and Australia ${ }^{59}$ have written requirements for constitutional amendment that are unusually onerous. In both countries, it is practically difficult to conduct wholly successful constitutional amendment campaigns. ${ }^{60}$ Given the fact that almost every constitution worldwide imposes some form of super-majority requirement for successful constitutional amendment, this has negative bearings on the chance of successful textual constitutional change. ${ }^{61}$ In the United States, the difficulty to adhere to the amendment procedure outlined in Article V of the US Constitution has rerouted the pursuance of constitutional from formal to informal amendment. ${ }^{62}$ The difficulty of formally amending the Constitution has accordingly forced political actors to update the Constitution informally through non- Article $\mathrm{V}$ methods, leaving the actual constitutional text unchanged. ${ }^{63}$ Some argue that the amendment procedures under Article V are too cumbersome and erratic to serve as the sole vehicle for constitutional development in a complex and rapidly changing society. ${ }^{64}$

There are several other more flexible modes of constitutional change that do not rely on the mechanistic procedures of Article $\mathrm{V}$ in order to keep the constitutional regime current and reflective of new social and political equilibria. ${ }^{65}$ These modes enable constitutional change by political adaptation as well as legislative and executive bodies. Such informal constitutional amendment mechanisms have drawn growing attention within governments and among scholars as they are ubiquitous and inevitable. ${ }^{66}$ This flows from the inevitable fact of informal ways of introducing changes in the life of a constitution, as a result of the rigidity of formal constitutional amendment methods and given the quantity and generality of a written constitution. Therefore, informal constitutional amendment procedures may play a role in reconstituting constitutional meaning in response to cumbersome constitutional amendment requirements. As a result, non-text-based constitutional changes can attain the objectives of formal amendment mechanisms in resetting the constitutional meaning for subsequent constitutional developments.

\footnotetext{
${ }^{59}$ These two countries are known for introducing change in their constitutions informally, and are being cited in a numbers of scholarly articles for so doing.

${ }^{60}$ Dixon (2010), supra note 20, p. 9.

${ }^{61}$ Ibid, p. 10.

${ }^{62}$ Albert, (2014), supra note 1, p. 1051.

${ }^{63}$ Id., pp. 1051-2.

${ }^{64}$ Id., p. 1052.

${ }^{65}$ Ibid.

${ }^{66}$ Albert, (2013), supra note 24, p. 225.
} 
It should be noted that a constitution does not specifically list informal amendment processes as forms of its modification. ${ }^{67}$ Rather, these methods depend on interpretations of what the constitution says and on interpretive understanding of the underlying intent. ${ }^{68}$ These may happen where there are new situations, which cannot be addressed by existing provisions of a constitution, or when there are gaps in an existing constitution. In these scenarios, courts and the representative bodies interpret provisions of a constitution in a creative manner to keep the constitutional regime up-to-date and reflective of new social and political changes without relying solely on the formal procedure. This is because it is not feasible to rely on formal constitutional amendment procedures for all unfolding new circumstances and gaps in a constitution created by dynamic realities. Against this backdrop, one may dare argue that informal constitutional amendment procedures may somewhat have remote constitutional base.

\section{Informal Constitutional Amendment}

As highlighted in the preceding sections, constitutional change can occur in the course of its application even in the absence of formal amendments. ${ }^{69}$ Most countries with difficult constitutional amendment procedures have developed "non-textual" alternatives of introducing constitutional changes, inter alia, through judicial review. ${ }^{70}$ So, the level of rigidity has direct repercussions on the extent to which the courts and the representative bodies interpret provisions (more informally) in a creative manner. ${ }^{71}$ These informal mechanisms mainly result from experiences of government action under the constitution. Hence, informal amendment is the need to correct constitutional deficiencies with diligence and efficacy. ${ }^{72}$

There are different types of informal change in the constitutional arrangement of a country. The first possibility is gradual revision of the

${ }^{67}$ Boundless. "Informal Methods of Amending the Constitution: Societal Change and Judicial Review." Boundless Political Science. Boundless, 08 Aug. 2016. Retrieved 07 Oct. $\quad 2016<\mathrm{https} / /$ www.boundless.com/political-science/textbooks/boundless-politicalscience-textbook/the-constitution-and-the-founding-of-america-2/amending-the-

constitution 28/informal-methods-of-amending-the-constitution-societal-change-andjudicial-review-168-5169/>

68 Ibid.

${ }^{69}$ Rasch, supra note 10, p. 9.

${ }^{70}$ Iris Nguyên-Duy, (2013), Playing Doctor Frankenstein when Re-forming the Constitution? Some thoughts on recent developments in the United Kingdom and Norway, a Paper for the international Conference "The Importance of Constitutions" Held at the Swedish Institute in Istanbul, Turkey, 23-25 October 2013, p. 9.

${ }^{71}$ Ibid.

${ }^{72}$ Id., p. 11. 
constitutional framework by means of judicial interpretation. ${ }^{73}$ Strauss, for example, argues that in the US, the Supreme Court generally interprets "the Constitution more or less in line with the kinds of changes in circumstances, understandings and even majoritarian demands that can lead to successful" constitutional amendments. ${ }^{74}$

The second possibility is revision of the constitutional text by irregular means. There are constitutional amendments that would not have been valid if the formal amendment and ratification process laid down in a constitution had been strictly followed. ${ }^{75}$ One can find several examples of constitutional changes that do not follow the formal processes laid down in the constitution. The Sherman Antitrust Act of 1890, the Civil Rights Act of 1964, and the Endangered Species Act of 1973 are suggested examples of informal amendments in the United States without adhering to amendment requirements stated in Article V. ${ }^{76}$ The third possibility is intended or unintended revision of the constitutional framework by means of political adaptation through legislative and executive bodies. ${ }^{77}$ Such informal amendments include legislation, judicial interpretation, executive action and convention. ${ }^{78}$.

\subsection{Legislation}

The framers of a constitution create the basic skeleton of different institutions, and they entrench particular solutions to a relatively narrow set of questions. For the rest, they seek to create a set of political institutions and empower those institutions to deal creatively with ongoing developments that cannot be effectively addressed by solely using the formal text in the constitution. ${ }^{79}$ Therefore, there may be many other documents that supplement the text of the constitution and provide for the actual set of constitutional rules ${ }^{80}$ These might include court decisions and legislation that provide for core aspects of governance and supplement the formal text. In the latter case, constitutional

\footnotetext{
${ }^{73}$ Rasch, supra note 10 , pp. 3-4.

${ }_{75}^{74}$ Dixon (2011), supra note 8, p. 96.

${ }^{75}$ Rasch, (2008), supra note 10, pp. 3-4.

${ }^{76}$ Albert, (2014) supra note 1, p. 1063.

${ }^{77}$ Rasch, supra note 10, pp. 3-4.

${ }^{78}$ Albert (2014) supra note 1, p. 1062.

79 See for example, Ernest Young A. (2007), "The Constitution Outside the Constitution", Yale Law Journal, Vol. 117, pp. 408-473, p. 456.

${ }^{80}$ Tom Ginsburg, (2010) “Constitutional Specificity, Unwritten Understandings and Constitutional Agreement”, in A. Sajo and R. Uitz, eds., Constitutional Topography: Values and Constitutions, Eleven international publishing, in The Netherlands, p.73.
} 
documents are described as the 'law for making laws' through which all other laws are made and enforced. ${ }^{81}$

Constitutions include some of the most fundamental rules. These include rules about the machinery of government and make general specifications about rights of citizens. These constraints enable the legislature to make further law/decisions to achieve objectives of the constitution while reducing the risks of violating constitutional principles. These are a few mechanisms available to the legislature, outside formal amendment, to influence constitutional meaning. Empowering a legislature to detail the general principle is sufficient condition to alter and influence a meaning in a constitution. This enables informal amendment through national legislation. ${ }^{82}$

The legislature has been a major agent in informal constitutional amendments in two ways. First, it passes many laws to spell out several of a constitution's brief provisions. ${ }^{83}$ Often, constitutions endeavour to set out the major tasks of governments and generally outline many issues in a holistic manner. Therefore, taking the general principles enshrined in a constitution into account, these matters should be governed by legislation. This is one way of making necessary changes in the provision of a constitution. Second, the legislature adds to a constitution the way in which it uses its powers. ${ }^{84}$ As Rosalind Dixon notes:

A principle of partial amendment does not purport to allow a legislature to add to or subtract from the text of the Constitution outside the requirements of amendment procedures. Rather, it allows legislature to provide information to the Court, with a view to influencing the Court's interpretation of existing constitutional text. ${ }^{85}$

In the United States, the theory of 'super-statutes' illustrates, with important limitations, how national legislation informally amends a constitution. ${ }^{86}$ There are certain statutes (in the US) that are passed in the normal course of the legislative process but acquire quasi-constitutional status. However, these statutes are expected to fulfil four criteria to obtain such status. ${ }^{87}$ First, they introduce a new principle or policy whose effect is substantial. Second, the new principle or policy becomes foundational or axiomatic to political actors. Third,

${ }^{81}$ Roger D. Congleton, (2003), Improving Democracy through Constitutional Reform, Some Swedish Lessons, Kluwer Academic Press, Boston, p. 11.

${ }^{82}$ Albert (2014) supra note 1, p. 1063.

${ }^{83}$ Johnson Carl. Informal Amendment <www.jenksps.org/pages/uploaded_files/Informal\%20Amendment.pdf>

${ }^{84}$ Ibid.

${ }^{85}$ Dixon (2011), supra note 8, p. 670.

${ }^{86}$ Albert(2014), supra note 1, p. 1063.

${ }^{87}$ Ibid. 
they result from long and deliberative public discussions and substantial reflection by political actors. Fourth, they require some elaboration from officials and judges in order to achieve their intended effect. ${ }^{88}$

Super-statutes, which fulfil these criteria, acquire their normative force through a series of public confrontations and debates over time. Super-statutes influenced by social norms may occasionally change constitutional meaning. They do so by trumping ordinary legislation and by establishing 'foundational principles' against which people presume their obligations and rights are set, and through which interpreters apply ordinary law. The Sherman Antitrust Act of 1890, the Civil Rights Act of 1964, and the Endangered Species Act of 1973 are suggested examples. In addition to the aforementioned Acts of the United States, the United Kingdom Human Rights Act of 1998, the Canadian Bill of Rights of 1960, and the Canada Health Act also constitute typical examples of super-statutes. ${ }^{89}$

\subsection{Constitutional interpretation}

Constitutional interpretation has two meanings. The first meaning, usually regarded as the classic meaning, "relates to the review of constitutionality of laws and actions of the state authorities that contravene the constitution". ${ }^{90}$ The second "meaning of constitutional interpretation is what we can call expounding on the text of the constitution" and it "may relate to any type of dispute that may arise in relation to the constitution or its provision", as in the case of a dispute "whether two provisions or principles in the constitution conflict with each other" thereby rightly becoming "a matter for constitutional interpretation". 91 Moreover, a gap in the constitution regarding important constitutional rights or principles may become a matter of constitutional interpretation. ${ }^{92}$

Drafters of constitutions often use general provisions, which are composed of ambiguous terms that provide flexibility to compromise. ${ }^{93}$ Given the quantity and generality of a constitution, it is not surprising that such a document requires interpretation. ${ }^{94}$ Constitutions proclaim all the values their framers believe essential to a good society but do not prioritize those values. Resolving conflict among basic values is thus left to the implementers and interpreters. ${ }^{95}$ However, constitutional provisions often offer little specific guidance for the

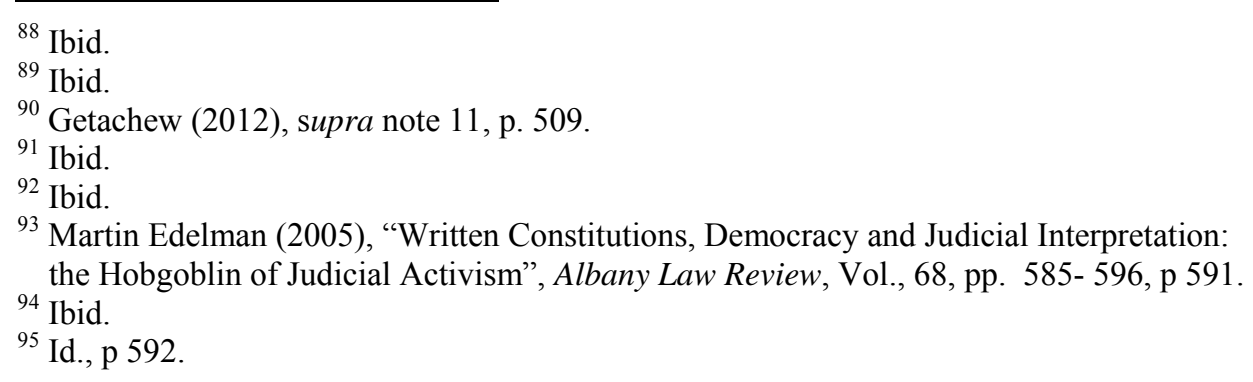


resolution of particulars in constitutional claims. ${ }^{96}$ This makes it necessary for constitutional adjudicators to specify the meaning of the provision in the context of actual cases. ${ }^{97}$ Wherever there is a written constitution whose "text is indeterminate, the courts are called upon to fashion a meaning". ${ }^{98}$ It is in this sense that "constitution amendment processes tend to be linked to judicial interpretation". 99 Thus, constitutional interpretation, unlike ordinary law cases, has greater impact in shaping a constitutional order. ${ }^{100}$

In the United States for instance, interpreting the constitutional text has been the preeminent activity of the Supreme Court for nearly two centuries. Indeed, the Supreme Court interpreting the written constitutional text is the essence of constitutional law in the United States. Courts, especially the Supreme Court, interpret and apply the Constitution in all of the cases they hear. ${ }^{101}$ In an event when the court declares that the words of a provision are plain and clear, or in situations where several meanings are possible and one meaning is chosen over the other, one can imagine its effect in shaping the constitutional text.

A Supreme Court judgment that interprets a vague constitutional provision might amount to an unwritten constitutional amendment. ${ }^{102}$ The Supreme Court has, from time to time, amended the United States Constitution without implementing the procedures required by Article V. ${ }^{103}$ At this stage, it is possible to argue that in the United States, interpreting a constitution may involve constitutional amendment. Informal amendment by judicial interpretation is more likely to occur in countries with a low rate of formal amendment and a long-established constitution. The practices in Australia, Finland, and Ireland as well suggest frequent informal amendment by judicial interpretation as a supplement to the formal amendment process. ${ }^{104}$

\footnotetext{
${ }^{96}$ Renáta Uitz (2005), Constitutions, Courts and History: Historical Narratives in Constitutional Adjudication, Central European University Press, Budapest, Hungary, p.63. ${ }^{97}$ Id., p. 67.

98 Sheldon D. Pollack, (2004), "Constitutional Interpretation from Two Perspectives: Canada and the United States", in Stephen L. Newman, ed., Constitutional Politics in Canada and Unite States, State University of New York Press, Albany, p. 36.

${ }^{99}$ Dixon (2011), supra note 8, p 96.

${ }^{100}$ Assefa Fiseha (2002), “A New Perspective on Constitutional Review”, Tilburg Foreign Law Review, pp. 237-255, p. 244.

${ }^{101}$ Pollack (2004), supra note 98, p. 36.

${ }^{102}$ See for example, Albert, (2010), Non constitutional Amendments, supra note 48, p. 13.

103 Eric J. Segall (2013), "Constitutional change and the Supreme Court: the Article V Problem", Journal of Constitutional Law, Vol.16, No.2, pp. 443- 451, p 451.

${ }^{104}$ Albert (2014) supra note 1, p. 1063.
} 


\subsection{Practices of political parties}

Political parties have been major players in the shaping of governments. The structure of party systems and "the way political parties are organized might reinforce or corrode the federal division of powers". ${ }^{105}$ There is also "a strong correlation between government party leaders tampering with the constitution to secure more terms than what is constitutionally permitted and the flaring up of acute conflict" ${ }^{106}$ Therefore, "the roles played by political parties are important determinants in the operation of federal systems" 107 and can affect the constitutional and institutional guarantees. Constitutional and institutional guarantees are meant to prevent political leaders at the central level of the federation from breaking the rules or changing the federal bargain unilaterally. These guarantees could be ineffectual when one homogeneous party controls both levels of government, because then it is more unlikely that there will be opposition against the change. ${ }^{108}$

\subsection{Political norms/ political custom}

Custom implies usual practices that have no formal obligatory effect. ${ }^{109}$ Despite its light obligatory nature, unwritten political custom may be as strong as written laws. ${ }^{110}$ Political norms change or construct the constitution so as to bring it in line with policy preferences. ${ }^{111}$ A well-established practice, which has been developed within a given political system, could alter the constitutional regime. ${ }^{112}$ By the same token, constitutions may alternatively be amended informally by political norms/political customs. This occurs when a political practice is adopted and repeated, and gradually hardens over time without expressly overturning constitutional provisions. This also takes place by means of usage within the legislative and executive bodies. ${ }^{113}$ In this regard, constitutions are susceptible to informal amendment through an established

105 Lovise Aalen (2002), Ethnic Federalism in a Dominant Party State: The Ethiopian Experience 1991-2000, Bergen, Chr. Michelsen Institute Development Studies and Human Rights, No2, p. 20.

${ }^{106}$ International Institute for Democracy and Electoral Assistance (2007), Political Parties in Africa: Challenges for Sustained Multiparty Democracy. p. 91.

${ }^{107}$ Aalen (2002), supra note 105, p 20.

${ }^{108}$ Ibid, p. 21.

109 Tadesse Melaku (2012), Introduction to Constitutional Law, Vol. I, Far East Trading P.L.C, p. 175.

${ }^{110}$ Carl, supra note 83.

111 Albert, (2014) supra note 1, p. 1062.

112 David A. Strauss, (1999), Do Constitutional Amendments Matter? University of Chicago Law School, Public Law and Legal Theory Working Paper No. 05, p. 20.

${ }^{113}$ Tadesse, supra note 109, p. 175. 
political custom. This occurs when a political practice is adopted and repeated, and gradually hardens into what Gerhardt calls "non-judicial precedent." 114

An example in this regard is the issue "whether the Vice President of the United States becomes President upon the President's death, or whether the Vice President simply assumes the powers and duties of the presidency as a caretaker. The text of the United States Constitution is ambiguous on this point". ${ }^{115}$ Vice President John Tyler resolved the ambiguity upon the death of President William Harrison in 1841. ${ }^{116}$ The Tyler precedent resolved the question left open by the constitutional text. Subsequent Vice Presidents followed the Tyler precedent and proclaimed themselves President when they succeeded to the presidency. ${ }^{117}$ Although Tyler's claim probably contradicted the framers' intent, later Vice Presidents who found themselves in that situation embraced his position and ultimately the Tyler precedent is accepted as constitutional reality. ${ }^{118}$

\section{The Ethiopian Legal Regime on Formal Constitutional Amendment}

The FDRE Constitution embodies provisions that spell out how the Constitution can be amended. ${ }^{119}$ These provisions are designed to ensure the involvement of states in incidents of constitutional amendment. The provisions embody clear procedural requirements toward formal amendment, and they show how a constitutional proposal, which is formally initiated and ratified, is inscribed in the constitutional text. Therefore, those amendments that pass through the conventional vehicles of formal amendment process become valid to all intents and purposes as part of the Constitution.

Although the Constitution expressly provides for the mechanisms of constitutional amendment, there are no express 'eternal clauses' that make some constitutional provisions non-amendable. It does not even prohibit the abrogation of or impediments to the rights conferred in Chapter Three of the Constitution (titled Fundamental Rights and Freedoms) with a view to rendering such amendment/s unconstitutional. ${ }^{120}$

\footnotetext{
${ }^{114}$ Albert, supra note 1, p. 1070.

${ }^{115}$ Ibid.

116 Ibid.

${ }^{117}$ Ibid.

118 Ibid .

${ }^{119}$ See article 104 and 105 of the FDRE Constitution.

${ }^{120}$ The FDRE Constitution specially mentions which provision is not derogated during the state of emergency. However, neither art 105 nor other parts of the Constitution indicates a right that is not subjected to formal constitutional amendment.
} 
Formal amendment procedures usually identify the individuals, institutions or bodies that are authorized to propose amendment to the existing constitution. However, the FDRE Constitution does not expressly indicate who can propose an amendment, be it group of individuals or institutions, and the procedure to be followed for the initiation of constitutional amendment. ${ }^{121}$ Fasil argues that the "formal initiation of constitutional amendment can come from either the regional or federal legislative organs". ${ }^{122}$ He further states "where the initiation comes from the regional states, a two third of state councils must support the draft amendment by majority vote. Otherwise, either of the federal Houses can initiate a constitutional amendment by a two third majority vote". ${ }^{123}$ One can possibly infer from Fasil's argument that an amendment to the Constitution can be tabled either by the federal Houses or State Councils but not by the general public.

On the other hand, the Constitution requires a proposed constitutional amendment to be submitted for discussion and decision to the general public and to whom the amendment of the Constitution concerns. ${ }^{124}$ This can be done if the proposal for constitutional amendment is supported by a two-third majority vote in the House of Peoples' Representatives (hereinafter, HoPR), or by a two-third majority vote in the House of Federation or when one third of the State Councils of the member States of the Federation, by a majority vote in each Council. ${ }^{125}$ The role of the public seems either to approve the proposed amendment whenever it provides for a better protection, or reject the proposal when a proposed amendment adversely affects the minimum constitutional privileges. If the general public stands against the proposed amendment, an issue arises whether the views of the legislative council or the general public would prevail.

The first line of argument is based on Article 105 of the FDRE Constitution that deals with constitutional amendment. This provision does not prohibit the submission of constitutional amendment proposal to the federal and regional state legislative councils for consideration if it is rejected by the general public. As a matter of fact, the Constitution does not indicate the role of the general public in the ratification process. It only mentions the involvement of the members of the federal Houses and regional state councils. One can thus argue that any proposal of constitutional amendment may be submitted for approval irrespective of its rejection by the general public. A bill, which is approved with

${ }^{121}$ See article 104 of the FDRE Constitution.

${ }^{122}$ Fasil Nahum, (1997), Constitution for a Nation of Nations: The Ethiopian Prospect, The Red Sea Press, p. 60.

123 Ibid.

${ }^{124}$ See article 104 of the FDRE Constitution.

${ }^{125}$ See article 104of the FDRE Constitution. 
the involvement of the legislative councils of both levels of government, becomes part of the constitution.

On the other hand, the aforementioned argument can be regarded as incongruent with the sovereign power of people since the members of the legislative councils are representative of the people. It is true that principally sovereignty lies on the people. ${ }^{126}$ What follows from this is that the constitutional amendment process should be controlled and owned by the people who form state power. This leads to interrogating the legitimacy of legislative councils to act contrary to public need. Even if both have different tests, the need of the people should have greater weight on what should be included in and excluded from the Constitution.

Article 105 of the FDRE Constitution, titled "Amendment of the Constitution", provides for different amendment standards or amendment procedures to modify the various sections of the Constitution. The first category of procedures requires majority approval from both federal houses, in addition to simple majority vote from each of the nine regional states legislatures. This kind of amendment, for the purpose of the FDRE Constitution, may be characterized as special amendment. The second category of amendment formula requires a majority of both houses and majority approval from two third of the states' council. This sort of amendment can be referred to as ordinary/ general amendment.

\subsection{Ordinary/General amendment procedure}

This general amending formula applies to wider sections of the Constitution. This kind of procedure is applicable to all provisions of the Constitution other than those provisions, which are found in Chapter Three, Articles 105(1) and 104. A general amending procedure requires the assent of the two federal houses and two-thirds of the Councils of the member States of the federation. ${ }^{127}$ It requires approval by a simple majority vote in state council of member states, followed by the approval of the House of Peoples' Representatives and the House of Federation by two-third majority vote in joint sitting. Thus, approval by a two-third majority in both houses, followed by ratification from the legislatures of two-third of the states, by majority vote, is a sufficient condition to endorse the proposed amendment.

${ }^{126}$ Getachew Assefa (2010) "Parliamentary oversight and Constitutionalism in Ethiopia: An Appraisal", in Assefa Fiseha and Getachew Assefa,(eds.) Institutionalizing Constitutionalism and Rule of law: Towards a constitutional Practice in Ethiopia, Ethiopian constitutional Law Series, Vol. 3 pp. 152-182, p125.

${ }^{127} \mathrm{See}$ article 105(2) of the FDRE Constitution. 


\subsection{Special amendment procedure}

A special amendment procedure is enshrined in the Constitution to amend some sections of the Constitution. These are Chapter Three, ${ }^{128}$ Articles 104 and 105. The matters that fall within the scope of this stringent standard are the sections that deal with fundamental rights and freedoms and a provision that deals with constitutional amendment. These provisions require the unanimous assent of all member states, by majority vote, followed by the approval of the federal houses, sitting and voting separately, in which the requisite approval must be a 'double majority' of votes, which involves members of House of People Representatives and House of Federation. ${ }^{129}$

The general and special amendment procedures are applicable to amend the Constitution formally in a textual manner. This means that FDRE Constitution authorizes amendments that respect the textual strictures of the Constitution. In contrast, there is the inclination toward informal constitution changes in the course of application in Ethiopia. Probable reasons for this seem to be the political cost and financial implications of formal constitutional amendment. A case in point in this regard relates to failed efforts to amend article 98 of the Constitution shortly after the amendment proposal passed a number of stages. This gives us insight as to why a dominant party's power in government does not necessarily guarantee the introduction of any kind of amendment the party wants to make.

Formal constitutional amendment may cost the government politically. Opposition political actors had intensified call for constitutional change specifically to amend some of the provisions of the Constitution. ${ }^{130}$ However, the EPRDF considers the Constitution as the foundation of the nation and it argues that any plan to amend the Constitution goes against constitutionalism. The EPRDF has also made bold statements describing the FDRE Constitution as one of the best constitutions in the world and not subject for amendment in recent decades. After having made these statements, engagement in formal constitutional amendment, might seem contradicting oneself. It opens, perhaps, room for further questions of constitutional amendment, which could be unwelcomed by the EPDRF and its supporters. More importantly, most of the informal changes made against the Constitution have the effect of increasing the power of the federal government. If the government makes similar changes by

${ }^{128}$ However, some argue that the special amendment procedure is not only applicable to provision of Chapter Three but also to those provisions that are directly related to Chapter Three but are not in Chapter Three, such as article 93 dealing with the suspension of rights that are embodied in Chapter Three.

${ }^{129}$ See article 105(1) of the FDRE Constitution.

${ }^{130}$ There has been frequent claim form opposition political parties, in particular, regarding the amendment of article 39 which deals with secession. 
pursuing the conventional textual method, the government will be blamed of tendencies toward more centralization officially in violation of the principles of federalism.

With regard to the financial cost, formal constitutional amendments at least, require arranging consultative meetings with the society as well as lobbying and convincing them that the amendment will not affect their interest. Such forums are necessary to ensure adequate deliberation on the potential advantages and disadvantages of any proposed constitutional change. ${ }^{131}$ Where this is the case, "the time- and therefore also opportunity cost- of debating proposed constitutional amendments will have a clear relationship with the size of the relevant voting body." 132

The more members are involved at various stages of a proposed constitutional amendment process, the longer will be the time that is required for discussion and decision. As the size of the participants increases, arranging consultative meeting, which enables the participants to exchange ideas and debate (over a benefit and disadvantage of the proposed amendment), will increase the time taken to introduce change and this has financial implication. Organizing forums frequently with the society to lobby and convince them that the amendment will not affect their interest will cost the government financially. This cost has the potential not only to increase but also become high when the participants of the forum are large in number. ${ }^{133}$

In this sense, the Ethiopian discourse of constitutional amendment makes sense when one considers how a constitutional amendment is initiated and how this proposed amendment is ratified. In Ethiopia, the process of constitutional amendment envisages the involvement of the general public, ${ }^{134}$ at various stages, i.e. the initiation stage, during the discussion and decision of the proposed constitutional amendment. Moreover, the FDRE Constitution also requires that any constitutional amendment "shall be submitted for discussion and decision to those whom the amendment of the Constitution concerns". ${ }^{135}$ One can argue that since the Constitution requires involvement of the general public and those communities "whom the amendment of the Constitution concerns", the amendment process will take more time and debating over a proposed constitutional amendment will have high cost. As a result, informal amendment seems to be the course pursued in Ethiopia to adapt the current Constitution with changing socio-economic and political situations and understandings.

\footnotetext{
${ }^{131}$ Dixon and Holden (2010) supra note 45, p 1.

${ }^{132}$ Ibid.

133 Ibid.

${ }^{134}$ See article 104 of the FDRE Constitution.

135 Ibid.
} 


\section{Informal Methods of Constitution 'Amendment': The Ethiopian Experience}

Informal amendment mechanisms have been the subject of great controversy in contemporary constitutional politics and there is controversy as to when a change is regarded as informal amendment. It should be noted that, every kind of informal amendment may not necessarily have the same kind of justification and each informal amendment method may be justified independently. As Albert notes, "It is difficult to pin down the difference in the substantive effects of the formal acts of amending the Constitution and the informal acts of interpreting it". ${ }^{136}$ For instance, in the US, informal amendment by judicial interpretation occurs when the Supreme Court interprets the Constitution as a final matter. In contrast, "judicial interpretation by lower courts is generally not nationally binding and it is therefore less accurate to define it as an informal amendment". 137

Second, even at the Supreme Court level, not all-constitutional interpretations cause an informal amendment. An informal amendment by judicial interpretation occurs where the Supreme Court confers constitutional status upon an unwritten constitutional principle. In such a case, there is no functional difference in constitutional effect between a textual rule entrenched in the constitution by formal amendment and an unwritten rule entrenched by judicial interpretation. ${ }^{138}$ With this state of affairs in mind, one can apply the same analogy to the decision of the House of Federation. The decision of the House is final over matters submitted to it and the decision of the House binds any government organ. ${ }^{139}$ The decision of the House remains binding unless it is changed by itself. The decision of the House has general effect, which can be applicable on similar constitutional matters that may arise in the future. ${ }^{140}$ This amounts to altering a constitution through unusual mechanisms or informally.

Political norms/custom is the other mechanism of making an informal constitutional amendment. When a constitution is ambiguous and where political actors consciously establish a new democratic practice that has been adopted and repeated, this can be regarded as informal constitutional amendment if the repetition of the new practice is intended to compel their

${ }^{136}$ Richard Albert (2015), 'Constitutional Amendment by Stealth, Boston College Law school', Research paper 357, McGill Law Journal, p. 12.

${ }^{137}$ Ibid.

138 Ibid.

139 See article 56(2) of Proclamation No. 251/2001, Proclamation of Consolidation of the House of the Federation and the Definition of its Powers and Responsibilities, Federal Negarit Gazeta, $7^{\text {th }}$ Year No. 4, Addis Ababa , $6^{\text {th }}$ July, 2001.

${ }^{140}$ Id., article 11(1). 
successors into compliance,. This occurs when a political practice gradually hardens into what Michael Gerhardt calls "non-judicial precedent" that is accepted as constitutional reality. ${ }^{141}$

As far as constitutional amendment by legislation is concerned, there may be certain legislations that are passed in the normal course of the legislative process but acquire quasi-constitutional status. This is the case where there is a newly introduced principle or policy whose effect is substantial. Moreover, the new principle or policy becomes foundational to political actors and results from long and deliberative public discussion and substantial reflection by political actors. If a given legislation rearranges the constitutional powers, it has the equivalent effect of an amendment and its effect is indistinguishable from a formal amendment so long as both bind political actors.

In this respect, one can take the instance of the Dire Dawa City Charter. There were claims made by the Oromia and Somalia regions over Dire Dawa city administration. Until the claims of these regional states were resolved, as per the decision of the government, the HPR passed a law granting selfadministration of the city in the meantime. Although the timeline to decide whether the city belongs to the Oromia or Somali regions had lapsed, the federal government continued to make special laws to ensure self-governance of the people of Dire Dawa city administration and made the city accountable to it. There were questions regarding the constitutional base of the charter. This legislation which vests autonomous powers to the city can be cited as an amendment to the Constitution through legislation.

It is not difficult to mention instances of actual unwritten constitutional change in Ethiopia. One example of informal change is the growth in the range of federal power. The text of the Constitution defines the scope of federal powers. ${ }^{142}$ Deviating from this, the federal government may now regulate subject matters that a decade ago would have been regarded as concurrent powers of both tiers of government. No formal amendment to the Constitution authorizes this expansion of federal government's power. This expansion in federal power comes about principally through government decision.

Our constitutional account has seen many developments that must be regarded as changes of constitutional magnitude, but that have not been accompanied by a formal amendment. The examples in this regard include the taking away of the joint power of taxation by the federal government, enacting Dire Dawa City Administration Proclamation, and conferring the mandate to

${ }^{141}$ Albert (2014), supra note 1, p. 1070.

${ }^{142}$ See article 51 cum 55 of the FDRE Constitution. 
organize intergovernmental relation to the federal government. ${ }^{143}$ On the other hand, empowering regional states to decide identity questions, accepting the supremacy of federal laws by regional states and enforcing federal laws by their own right are some of the instances which have taken place informally although they need constitutional amendments. These aspects of change in our system have to be considered fundamental enough to assume constitutional magnitude.

\subsection{Constitutional interpretation: The Silte case}

Constitutional interpretation is one of the customary means by which constitutions are adapted to changing political, social or economic realities. ${ }^{144}$ It is in this sense that the FDRE Constitution empowers the House of Federation to entertain matters that give rise to constitutional dispute. ${ }^{145}$ Thus, a constitutional dispute, in the context of the Ethiopian Constitution, has two aspects: the first relates to general task of interpreting the Constitution with a view to ascertain the meaning, content and scope of a constitutional provision, and the second aspect refers to the task of determining the constitutionality of "federal or state law". 146

Pursuant to the first aspect, the House may modify the contents of the Constitution in the course of asserting or defining the scope of a certain term. On the other hand, if the federal government overreaches or derogates, through its law or other decision, the powers and interests of the states against the federal Constitution's division of powers, this could be corrected by the House of Federation through its power of constitutional interpretation. ${ }^{147}$ The decision of the House is applicable on other similar constitutional matters that may arise in the future. ${ }^{148}$ This amounts to altering a constitution through unusual mechanisms or informally. The following decision of the House in the Silte case illustrates an informal constitutional amendment.

${ }^{143}$ Solomon, supra note 18, p.32. See also the first paragraph of the Preamble, Proclamation No. 416/2004 the Dire Dawa Administration Charter Proclamation, $10^{\text {th }}$ Year No. 60, Addis Ababa, $30^{\text {th }}$ July, 2004.

${ }^{144}$ Gabriel L. Negretto (2008), The Durability of Constitutions in Changing Environments: Explaining Constitutional Replacements in Latin America, the Helen Kellogg Institute of International studies, working paper, No, 350, p. 8.

${ }^{145}$ See article 83(1) of the FDRE Constitution .

146 Yonatan Tesfaye (2008), "Whose Power Is It Anyway: The Courts and Constitutional Interpretation in Ethiopia”, Journal of Ethiopian Law, Vol. 22, No.1 pp. 128- 144 p 134.

${ }^{147}$ Getachew Assefa, (2008) Book Review on Assefa Fiseha, Federalism and Accommodation of Diversity in Ethiopia: A Comparative Study (Revised Edition: 2007) Addis Ababa: Artistic Printing Enterprise. pp. xv; 480. Journal of Ethiopian Law Vol. 22 No. 2 pp. 189-203, p. 101.

${ }^{148}$ See article 11(1) Proclamation No. 251/2001, supra note 139. 
This case was initially filed in the House of Federation. ${ }^{149}$ The applicants filed their case to the House alleging that Silte had been considered Gurage against their will for a long period, although they are not truly Gurage. ${ }^{150}$ They argued that Silte people have their own language, territory and history, which are unique from Gurage. They contended that being considered as Gurage contravenes with their right to self-determination and amounts to complete denial of their right to self-government. The relief they sought from the House was to ensure their right to self-determination, which is constitutionally granted, by recognizing them as distinct ethnic group separate from the Gurage. ${ }^{151}$

The House referred the case to the Council of Constitutional Inquiry (hereinafter called, CCI) to make the necessary investigation and come up with fitting recommendation on the following issue: Who can determine if a given community claims self-determination asserting that it fulfils all criteria specified in Article 39(5) of the FDRE Constitution. ${ }^{152}$ Upon reviewing the case, the CCI framed the following questions for consideration: who shall decide on questions that arise in the determination of ethnic identity of a given community under the FDRE Constitution? What is the procedure that should be followed to reach a decision on such matters?

Upon its investigation, the CCI made the necessary examination on the Constitution and concluded that there is hardly any clear and specific constitutional provision that directly addresses these issues. ${ }^{153}$ Then, it accepted the fact that the Constitution is silent with regard to these matters. The CCI was working on how the silence of the Constitution can be construed. The CCI identified four potential provisions of the Constitution, i.e., Articles 39(4),

${ }^{149}$ Getahun Kassa (2007), "Mechanisms of Constitutional Control: A Preliminary Observation of the Ethiopian System", Afrika Focus, Vol. 20, Nr. 1-2, 2007, pp. 75-104 p. 90 .

150 Ibid.

${ }^{151}$ The House of Federation of Federal Democratic Republic of Ethiopia (2000), "Decision of House of Federation on Identity Claim of Silte Community", Journal of Constitutional Decisions, vol. 1, No. 1 pp. 41-101, p 41.

152 Article 39(5) of the FDRE Constitution enumerates different elements that need to be fulfilled by a given community to be considered as Nation, Nationality or People. It reads: "A Nation, Nationality or People for the purpose of this Constitution, is a group of people who have or share a large measure of a common culture or similar customs, mutual intelligibility of language, belief in a common or related identities, a common psychological make-up, and who inhabit an identifiable, predominantly contiguous territory."

${ }^{153}$ The House of Federation of Federal Democratic Republic of Ethiopia, supra note 151, p. 43. 
$47(2), 52(2)$ (a) and 62(3) as provisions that might have relevance to address the questions at hand. ${ }^{154}$.

The CCI embarked on an investigation with an attempt to check whether Article 39(4) is appropriate to regulate the matter. The CCI stated that Article 39(4) is essential to determine the right to secession of nations, nationalities and peoples of Ethiopia. ${ }^{155}$ Since their question was to get internal selfdetermination rather than withdrawal from the jurisdiction of Ethiopia -and to create a new sovereign state-, this constitutional provision was considered as inapplicable to resolve the Silte case. The next provision examined by the Council is Article 47. The CCI viewed that this provision is invoked in cases where a given community is acknowledged as a distinct nation or nationality within the region in which it inhabits and claims to establish its own region. Hence, the CCI stated that this constitutional provision is not relevant to address the Silte claims.

The third constitutional provision, which was examined by the CCI, was Article 52(2 (a)), which pronounces that states shall have the power to establish a state administration that best advances self-government. ${ }^{156}$ When regional states establish state administration that best advances self-government, they are expected to take into account the language, settlement pattern and identities of the community, which seeks self-determination. Moreover, regional states that seek to establish state administration are expected to primarily determine the identity of the community concerned. Therefore, the mandate to determine the identity of a given community is left to regional states and is expected to be considered in the regional council in which the community that seeks selfgovernment inhabits.

The House (in its decision) indicated that in the process of determining this issue, the regional state council (to whom the claim is submitted) is expected to conduct referendum with direct participation of the community that has lodged the claim. According to the decision of the House, this should be conducted by secret ballot, in a free and fair manner and should be attended by impartial observers. However, if a community, which invokes an identity claim, is dissatisfied with decision of the State Council or if it feels that the decision of the State Council contradicts with the Constitution, it can appeal to the House of Federation. The House derives this power from the interpretation of Article 62(3) of the Constitution. The provision states that the House, in accordance

\footnotetext{
${ }^{154}$ Ibid.

155 Ibid.

${ }^{156}$ Ibid.
} 
with the Constitution, decides on issues relating to the rights of Nations, Nationalities and Peoples self-determination, including the right to secession. ${ }^{157}$

This decision is a breakthrough in updating the FDRE Constitution. The interpretation of the House in the Silte case adds new dimension which was not foreseen by the drafters of Constitution to be expressly included therein. The decision of the House updates the contents of the Constitution on three points. First, it empowers the regional states to determine the identity of a nation, nationality and people of Ethiopia. Second, the decision sets a time framework within which the identity determination claim that appears before a State Council shall be decided, by indicating in the decision that the concerned state council shall, within a year, render a decision on a dispute submitted to it. Third, the decision also authorizes the House of Federation to review the decision of the State Council if the claimant community lodges an appeal to it. The decision of the House will be final over the matter. The three points indicated hereinabove have general effect, which can be applicable on similar constitutional matters that may arise in the future. ${ }^{158}$

\subsection{Informal constitutional changes through legislation}

Starting from the Transitional Government after the downfall of the Dergue regime, the legislature has enacted numerous laws. The laws which were enacted before and after Constitution are required to be in conformity with the Constitution. This means, whenever the federal government enacts a law on certain matters, it is expected to show its constitutional source on the preamble of the legislation. In doing so, the federal government constitutionalizes its act of passing laws on the matter at hand. This stems from constitutional principles, which require the legislative body to indicate its constitutional source for those powers that can be exercised by any level of government. ${ }^{159}$ However, there are a number of proclamations, which are enacted by the HoPR without authority that emanates from the Federal Constitution.

\subsubsection{Dire Dawa city Administration Proclamation}

As highlighted earlier, there were claims made by the Oromia and Somalia regions over Dire Dawa city administration following the regional boundary demarcation. ${ }^{160}$ There was also a need to regulate self-determination of the Dire Dawa city residents by law until the claims of Somalia and Oromia Regions

${ }^{157}$ See Article 62(3) of the FDRE Constitution.

${ }^{158}$ See article 11(1) of Proclamation No. 251/2001, supra note 139.

159 Assefa Fiseha (2006), Federalism and the Accommodation of Diversity in Ethiopia: A Comparative Study. (Netherlands: Wolf Legal Publisher), p. 121.

160 See first paragraph of the preamble, Proclamation No. 416/2004 the Dire Dawa Administration Charter Proclamation, $10^{\text {th }}$ Year No. 60, Addis Ababa, 30 $0^{\text {th }}$ July, 2004. 
were finally resolved. ${ }^{161}$ It was thus decided (since 1993) that Dire Dawa City be accountable to and be directed by the Federal Government. ${ }^{162}$ It is this measure that enabled the federal government to pass a law that granted selfadministration to ensure good governance and expedite development in Dire Dawa City until a lasting solution is secured. ${ }^{163}$ It was based on this premise that the HoPR enacted Dire Dawa Administration Proclamation.

The Proclamation does not mention the constitutional basis that justifies the enactment of the Charter. However, the Charter is still functional and has not been declared unconstitutional. Pursuant to this charter, Dire Dawa is under the federal government in spite of competing claims from Oromia and Somalia regional states. The purpose of the legislation, according to the government, was to make it possible for the parliament to make special laws to ensure selfgovernance of the people of Dire Dawa city administration and to enable the federal government to co-operate with the States in searching a lasting solution for the claims of the two regions on the city.

Later on, the HoPR has revised the Dire Dawa City Administration Charter. The preamble of the revised Proclamation states that the amendment is made pursuant to Article 55(1) of the FDRE Constitution. ${ }^{164}$ However, the provision cited in the revised Proclamation or other parts of the Constitution do not entrust this mandate to the HoPR. One may thus argue that this illustrates informal constitutional amendment that increases the powers of the federal government by legislation.

\subsubsection{Intergovernmental relations (IGR)}

In Ethiopia, the Constitution essentially provides dual governmental structure and allots separate jurisdiction to each level of government. ${ }^{165}$ Though the jurisdictions of the federal government and the member states are distinctly delineated, there are important constitutional provisions emphasizing the need for consultation, coordination and collaboration. ${ }^{166}$ It is possible to argue that, the federal government and the constituent states are interdependent in a wide range of matters. However, the FDRE Constitution is vague regarding the

\footnotetext{
161 Ibid.

162 Ibid.

${ }^{163}$ Id., See, second paragraph of the preamble of Dire Dawa Administration Charter

${ }^{164}$ See preamble of Proclamation No. 483/2006, the Dire Dawa Administration Charter (Amended), $12^{\text {th }}$ Year No. 14, $5^{\text {th }}$ January, 2006 [Hereinafter called, Dire Dawa Administration Charter (Amended)].

${ }^{165}$ See article 50(2) of the FDRE Constitution.

${ }^{166}$ Nigussie Afesha (2015), "The Federal-state Intergovernmental Relationship in Ethiopia: Institutional Framework and its Implication on State Autonomy", Mizan Law Review, Vol. 9, No. 2, pp. 341-368: DOI: http://dx.doi.org/10.4314/mlr.v9i2.4
} 
mandate to make law concerning intergovernmental relations. A focal point for intergovernmental relation remains unanswered by the Constitution. This power is neither given expressly to the federal government alone nor concurrently to the federal government and the regional states. Therefore, it is possible to argue that this mandate is reserved to the regional states. ${ }^{167}$

Nevertheless, the HoPR construed the ambiguity of the Constitution by authorizing one of the institutions of the executive branches to perform IGR tasks. This issue is largely answered by Proclamation No. 691/2010 ${ }^{168}$ which authorizes the Ministry of Federal Affairs to serve as a focal point to organize IGR. ${ }^{169}$ The Proclamation sets general guidelines that regulate the relationship between the federal and the state governments. It requires that the federal-state relationship should be on the basis of a spirit of partnership and mutual understanding rather hierarchical relations ${ }^{170}$ with a view to ensuring sustainable peaceful coexistence and strengthening of the federal system. A question that inevitably arises is whether this amounts to giving extra mandate to the Ministry, which is not envisaged under the FDRE Constitution.

The same Proclamation has made modifications on the exclusive power of the House of Federation, which is given to the House by the Constitution. The Proclamation confers this exclusive power (of the House) upon the Ministry of Federal Affairs. Article 62(6) of the Constitution provides: "It (House of Federation) shall strive to find solutions to disputes or misunderstandings that may arise between States." Despite the existence of such constitutional provision, the mandate to facilitate the resolution of disputes arising between regional states, -so long as it does not contradict with the powers of the House of Federation- is given to the Ministry of federal Affairs. Article 14(1) (b) of the Proclamation reads: "without prejudice to the provisions of Article 48 and 62(6) of the Constitution of the Federal Democratic Republic of Ethiopia, the Ministry of federal Affair has the power to facilitate the resolution of disputes arising between regional states." By so doing, the legislation apportions the express constitutional powers of House of Federation so that it can be shared with the Ministry of Federal Affairs. This can be viewed as an informal way of introducing change on the provision of the Constitution.

\footnotetext{
${ }^{167}$ See article 52(1) of the FDRE Constitution.

${ }^{168}$ See article 14(1) of Proclamation 691/2010 'Definition of Powers and Duties of the Executive Organs of the Federal Democratic Republic of Ethiopia' Federal Negarit Gazeta $17^{\text {th }}$ Year No. 1, Addis Ababa $27^{\text {th }}$ October, 2010.

${ }^{169}$ Id., see article 14(1) (e). It should be noted that the proclamation was enacted principally to define the power of the Federal Executive Institutions.

${ }^{170}$ Ibid.
} 


\subsection{Law Enforcement, Administrative and Political Practices}

Institutional practice seeks to establish a new normative or institutional framework for state policy and, over time, it can be embedded in the public culture. Thus, political norms/practices and its institutional or normative principles have a broad effect on the Constitution including an informal constitutional amendment. There are many situations that are not regulated by a constitution but governed by political custom within the legislative and executive bodies. Such customary political practices have been designed for the purpose of adapting a constitution to new circumstances without affecting its legal continuity. In this sense, habitual institutional practices try to fill gaps in the Constitution and can be regarded as indicators of informal constitutional amendment. There are various political practices that emerge when a constitution is silent. The constitutionality of the practice may not be challenged because many practices may not clearly contradict express constitutional provisions.

The conduct of states in adopting the federal supremacy clause in their constitutions and various laws and in the enforcement of federal laws on matters that are not delegated to them are examples of issues that are not discernible from a reading of the FDRE Constitution. However, there is the practice in Ethiopia of enforcing federal law by states ${ }^{171}$ and considering federal law as supreme over state laws. In this regard, Assefa argues that the federal government has at least three ways to influence the state governments and facilitate the enforcement of federal laws and programs: namely, the Ministry of Federal Affairs, party structure and the process of policy making. ${ }^{172}$ Undoubtedly, these are powerful examples of unwritten constitutional principles that continue to guide the course of the Ethiopian federal state.

\subsubsection{Federal Law supremacy}

It is important to analyse the effect of enacting legislation by the federal government in the field of concurrent powers. "The Ethiopian Constitution is silent as far as the thorny issue of regulating the relationship between federal and state law" is concerned in case of conflict between state and federal law. ${ }^{173}$ There are certainly two views. Some scholars argue that the Ethiopian federal system adopts federal supremacy clause by default. ${ }^{174}$ But others adhere to the 'supremacy of nations, nationalities and peoples' and contend that federal law will not pre-empt state law. ${ }^{175}$ Assefa, states that "the best compromise is to

\footnotetext{
${ }^{171}$ Assefa, supra note 159, p. 355.

${ }^{172}$ Ibid, p. 376.

${ }^{173}$ Ibid, p. 329.

${ }^{174}$ Ibid.

175 Ibid.
} 
decide the issues on a case-by-case basis rather than subscribing to either principle at an abstract level". ${ }^{176}$

The practice of regional states and their constitutions support the existence of federal supremacy clause in Ethiopia. ${ }^{177}$ Normally, regional states acknowledge the supremacy of federal laws over inconsistent state laws. They give such recognition through their constitutions. ${ }^{178}$ In the first place, regional state constitutions describe the state council as the legislative body of the state and also vest the highest political power regarding internal affairs of the regional state. The same constitutions also include a provision that gives the state council the mandate to issue laws that are consistent with the Federal Constitution and other federal laws. ${ }^{179}$ It is true that the regional states' laws and federal laws are expected to be consistent with FDRE Constitution. However, the FDRE Constitution does not expressly state the supremacy of federal laws over state laws that are inconsistent to it. Nevertheless, most regional states subject their laws to the federal Constitution and other federal laws. This is one of the areas in which supremacy of federal law is admitted by the regional state. ${ }^{180}$ Solomon Negussie argues: "states Constitutions and legislations which came at the later stage affirmed that all laws and practices should not contradict the federal constitution as well as federal laws". ${ }^{181}$

\subsubsection{Cooperation through Executive Institutions}

Federal executive institutions execute federal laws, ${ }^{182}$ while regional governments may execute laws enacted by the federal government where the federal government delegates regional states to do so. The federal government is expected to grant this power through a proclamation, or this can be done through regulation when the legislative organ allows the executive organ to give its powers to its counterpart offices in the regional states. Departing from this principle, the Ministry of Justice (currently reorganized as the Federal Attorney

\footnotetext{
${ }^{176}$ Ibid, p. 330.

177 This kind of argument begs the question, does it the purpose of the regional states constitution, to undermine their powers and autonomy? The author would like to discuss this argument acknowledging the possibility of such kind of question would come from readers.

${ }^{178}$ See article 51(1) of SNNPR, 49(1) Amhara Regional states (Amharic version ) art 51(3)(3.1) Gambela Regional state, 47(3)(a)Afar regional state, 49(3)(a) Oromia regional state, 49(3)(a) Somalia regional state.

${ }^{179}$ Ibid. See also article 9(1) of the FDRE Constitution.

${ }^{180}$ See article 51(1) of SNNPR and other regional state constitutions, supra note177.

${ }^{181}$ Solomon Negussie, supra note 18, p. 65.

${ }^{182}$ See article 77(1) of the FDRE Constitution.
} 
General), for instance, delegates its power of prosecution to a regional justice bureau through a letter where an offence is committed in a given region ${ }^{183}$

This issue evokes further discussion. In order to file a criminal charge, the investigation is undertaken by a police officer. The issue then becomes whether the police officer at the federal or regional level makes the investigation. It is the Federal Police Commission that has the power to investigate crimes that fall under the jurisdiction of Federal Courts. ${ }^{184}$ But, the move to establish federal police institutions within regional states to effect arrest and make necessary investigation on federal criminal matters is inconsequential. Due to the absence of federal police officers who undertake criminal investigation, it is the respective regional officers who are undertaking criminal investigation in all states. Another question that needs clarification is whether regional police officers have the authority to do so.

In this scenario, one may possibly mention Proclamation No. 313/2003 (Federal Police Commission Proclamation) that requires the Federal Police Commission to work in cooperation with the Regional Police Commissions in the prevention and investigation of crimes. ${ }^{185}$ The Regional Police Commissions are accountable to the Federal Police Commission when they investigate criminal cases that fall under the jurisdiction of the Federal Courts in accordance with the delegation given to them. ${ }^{186}$ This provision denotes the situation that makes regional police organs accountable to the Federal Police Commission while they investigate federal criminal cases.

This proclamation implicitly answers the inevitability of delegation of powers. However, neither the Proclamation nor other regulations delegate regional police organs to make investigation on federal criminal cases. Even the Federal Police Commission does not delegate its powers to the regional state through letter. ${ }^{187}$ However, it is regular practice that the regional state police undertake investigation on criminal cases. This amounts to enlarging the powers of the regional state. This is also equivalent to informally amending the Constitution by disuse due to the fact that the Federal Police Commission has failed to establish and use its power of prosecuting offences in all regional states.

\footnotetext{
${ }^{183}$ See letter issued by the Ministry of Justice file number 01/A14/12/12, on 15/07/98 EC.

${ }^{184}$ See, Article 7(1) of Proclamation No. 313/2003, Federal Police Commission Proclamation, Federal Negarit Gazeta, $9^{\text {th }}$ Year No. 30, Addis Ababa, $4^{\text {th }}$ January, 2003. ${ }^{185}$ Id., Article 23(1)(2) of Federal Police Commission Proclamation.

${ }^{187}$ Interview with senior government police commissioner (whose anonymity is respected).
} 


\subsubsection{Ruling Party modus operandi and its influence on federal arrangements and development plans}

Political parties are extremely important elements of a federation. The nature of political parties and their internal operation has an impact on the working of a federation. ${ }^{188}$ The structure of party systems and the way political parties are organized might reinforce or corrode the federal division of powers. In general, the role played by political parties is among the major determinant factors in the operation of federal systems, ${ }^{189}$ and at times it affects the constitutional and the institutional guarantees. Constitutional and institutional guarantees are meant to prevent political leaders at the central level from changing the federal bargain unilaterally. However, these guarantees are ineffectual when one homogeneous party controls both levels of government because there will be no opposition against the change. ${ }^{190}$ This is because central decisions can substitute federal bargain. As Assefa argues, if one homogeneous party controls both levels of government, there would be no occasion for intergovernmental conflicts. ${ }^{191}$

The character of parties and party systems can affect the working of the whole federation. This is because a "political party is expected to harmonize the policies of the federal government and constituent states". ${ }^{192}$ Ethiopia, presently, is ruled by a coalition composed of several regionally based ethnic parties. Ethiopian Peoples Revolutionary Democratic Front (EPRDF) is controlling all the regional state governments in the Ethiopian federation; either directly through the member parties or indirectly through affiliated parties. ${ }^{193}$ As a result, the party structure in Ethiopia undermines the federal division of power and subordinates the regional governments to the federal government with particular emphasis on socio-economic development policies. ${ }^{194}$ It is clear that a mandate to make social, economic and development policies is distributed to the federal and state governments. Contrary to this constitutional power distribution, the Federal government, through the party line, has informally taken over the powers to make social, economic and development polices given to the federal and the state governments and has been engaged in preparing the same for both levels of government.

The practice in Growth and Transformation Plan is another area of practice which illustrates informal changes in federal arrangements. The FDRE Constitution clearly delineates the powers between the federal and member

\footnotetext{
${ }^{188}$ Aalen, supra note 105, p 20.

${ }^{189}$ Ibid, p 21.

${ }^{190}$ Ibid.

${ }^{191}$ Assefa, supra note 159, p 392.

192 Id, p. 385.

${ }^{193}$ Id., p. 387.

194 Ibid.
} 
states with respect to social, economic and development plans. ${ }^{195}$ Pursuant to this power distribution, the federal government is empowered to formulate and implement nationwide policies, strategies and plans with respect to overall economic, social and development matters. ${ }^{196}$ The Constitution authorizes regional states to prepare the same at state level: to formulate and execute economic, social and development policies, strategies and plans of the regional states. ${ }^{197}$ Despite this constitutional ruling, the social, economic and development strategic plan is prepared centrally for both levels of government. By implication, the power to make social, economic and development policies is shifted to the federal authorities. Under these circumstances, regional states draw their respective plan from the wider plan, which is generated and approved first through party lines. ${ }^{198}$

A central committee, which leads the ruling coalition, often through the chairman, generates specific plans of action, which are the basis for five-year plans that will be implemented nationwide. The five-year plan becomes the basis for the economic, social and development policies, strategies and plans of federal and state governments'. ${ }^{199}$ Apparently, both tiers of government are expected either to prepare their respective plans based on the document which is prepared through party line or to revise their plan in line with centrally prepared plan since they are under the direct control and influence of the ruling party. As a result, currently, the federal government and the states draw their respective plans from the wider plan, which is generated and approved first through party lines. ${ }^{200}$ This in turn undermines the constitutional mandate of the regional states to formulate and implement plans and policies of their own. ${ }^{201}$ They implement the social, economic and development plan prepared by the party line. The growth and transformation plan serves as the social, economic and development plan of the regional states. In so doing, the party line has taken away their power to make social, economic and development polices in the context of harmony.

\section{Concluding Remarks}

The embodiment of a mechanism for constitutional amendment is among the universal features of constitutions. The mechanisms of amendment denote the idea of correction or improvement of prior choices in constitutional design in light of new information, evolving experience or political understanding.

\footnotetext{
${ }^{195}$ See article 51(2) cum article 52(2)(c) of the FDRE Constitution.

${ }^{196} \mathrm{Id}$., article 51(2).

${ }^{197}$ Id., article 52(2)(2).

${ }^{198}$ Assefa, supra note 159, p. 388.

199 Ibid.

200 Ibid.

${ }^{201}$ Ibid, p. 389.
} 
However, significant controversy remains over the function of formal procedures for all kinds of constitutional amendment. Most constitutional scholars agree that not all forms of constitutional change in fact involve processes of constitutional amendment. Some scholars even suggest that formal constitutional amendments will be irrelevant to ultimately shape constitutional meaning. As a consequence, political actors frequently look for alternatives to formal constitutional amendment. Although the formal mechanism is a vital apparatus to modify a constitution, the role of non-constitutional mechanisms in the alteration of a constitution is also profound. Hence, the function, relation and co-existence of formal and non-formal mechanisms need to be clearly spelled out. The extent to which and the circumstances under which non-constitutional mechanisms modify the contents of the constitution need to be ascertained.

The FDRE Constitution, like many other constitutions, encompasses constitutional provisions that spell out how the Constitution can be amended. However, the Constitution has not been formally amended, except the unfinished move to amend it on a single occasion. The Constitution has served for more than two decades without substantial formal modification. On the other hand, it is not difficult to mention instances of actual unwritten constitutional changes in the Constitution. One of the means of informal change is through constitutional interpretation. This entails the possibility that decisions of the House of Federation can update the contents of the Constitution in the course of asserting or defining the scope of certain terms or provisions in general. The second instance where unwritten constitutional change in Ethiopia has taken place is when the federal government enacts a law on certain matters. There are a number of proclamations, which are enacted by the HoPR even if that particular power is not clearly given to the federal government. Proclamations that govern Dire Dawa City Administration and intergovernmental relation are some of the examples.

Another example of practices that is not discernible from the reading of the FDRE Constitution relates to the acknowledgment of federal law supremacy by regional states through their constitutions and their willingness to enforce federal laws on matters that are not delegated to them. It is to also be noted that the party structure in Ethiopia and its practices informally change the federal division of power and this setting subordinates social, economic and development polices of regional governments to the federal government. This is contrary to the constitutional power distribution given to the Federal and the State governments. In so doing, the party line has, without formal constitutional amendment, taken over the power of regional states to make social, economic and development polices. 